\title{
Muslim women's new defenders: Women's rights, nationalism and Islamophobia in contemporary Australia
}

Christina Ho

Lecturer

Social Inquiry Program, Faculty of Humanities and Social Sciences

University of Technology, Sydney

Address: PO Box 123, Broadway NSW 2007

Tel. +61-2-9514-1946

Fax +61-2-9514-2332

Email: christina.ho@uts.edu.au

Shortened title: Muslim women’s new defenders

Acknowledgements:

This paper draws on research funded by the Australian Research Council (Project title: Sanctuary and Security in Contemporary Australia: Muslim

Women's Networks 1980-2005, ARC Project ID: LP0562553). Thanks to Wafa

Chafic and Heather Goodall for their helpful comments on a draft of this paper. 


\section{Biographical statement}

Dr Christina Ho is a Lecturer in the Social Inquiry Program in the Faculty of Humanities and Social Sciences at the University of Technology, Sydney. Her research focuses on migration, gender and multicultural politics, with her current work focusing on Muslim women, security and community politics in Australia. 


\begin{abstract}
In recent years, Australian nationalism has been increasingly framed against a dangerous Muslim 'other'. This paper offers a gendered analysis of this nationalism, arguing that a discourse of protecting women's rights has enabled Islam to be portrayed as inherently misogynistic and therefore a threat to Australia's egalitarian culture. This racialised paternalism was clearly articulated in debates surrounding the December 2005 Cronulla riots, a response to the alleged aggressive and misogynistic behaviour of 'Lebanese Muslim' males at Cronulla beach in Sydney. The paper shows that such discursive acts are part of a broader history of colonial feminism that legitimated Western supremacy through arguing that colonised societies oppressed 'their women' and were thus unfit for self-governance, a logic which has also been commonplace in the recent war on terror. It concludes by exploring how Muslim women themselves can speak publicly about women's rights without fuelling further anti-Muslim racism.
\end{abstract}




\section{Introduction}

This paper documents the appropriation of the discourse of women's rights by conservative politicians and commentators in Australia and other Western nations, where a new-found 'concern' for women has become a means for the articulation of a paternalistic and anti-Muslim nationalism. The discourse of defending women's rights has arisen in the context of the global war on terror, and in Australia, local events such as the moral panic over 'Lebanese Muslim' gang rapes and the 2005 riots against 'Lebs’ at Sydney’s Cronulla beach.

Both Muslim and non-Muslim women are the subjects of this paternalistic, antiMuslim nationalism. The 'oppression' of Muslim women by their menfolk is used to portray Islam as inherently misogynistic and oppressive, while instances of Muslim men harassing and sexually assaulting non-Muslim women have triggered a nationalistic response founded on the protection of 'our women'.

This gendered discourse allows Muslim misogyny to be portrayed as a threat to national security, as lines of connection are drawn between the mistreatment of women and global terrorism. The success of this logic depends on the obscuring of misogynistic elements of mainstream Australian culture, enabling an essentialist bifurcation of 'egalitarian West' versus ‘oppressive Islam'.

In analysing these discursive constructions, I draw on the rich literature on colonial feminism, showing that current Australian debates are part of a long history of colonialist discourses that use gender relations to demonise other cultures and societies. As Said's Orientalism (1979) argued, East-West relations have long been framed by constructions of Oriental despotism, encapsulated by the 'maltreatment' of women.

Ultimately, the paper concludes that colonial feminist discourses jeopardise Muslim women's ability to speak out about social problems in their own communities, as their criticisms risk being absorbed into the dominant discourse of anti-Muslim racism. In a political climate that has pre-defined Islam as oppressive, any concerns Muslim women wish to articulate about violence against women or women's roles in the community risk becoming more evidence of the 'inherent' misogyny of their culture or faith, or providing ammunition for those seeking to attack multiculturalism or curtail the immigration of people from 'alien' cultures.

\section{Muslim Australians: A profile}

Muslim Australians are one of the fastest growing minority groups in the country. Their numbers almost doubled in the decade to 2001, to more than a quarter of a million (281,578), representing approximately 1.5 per cent of the total Australian population (HREOC, 2004: 213). Australia's Muslim population is ethnically diverse: in 2001, the largest groups were those claiming Lebanese (30 per cent) and Turkish (18 per cent) ancestry, with smaller groups including Afghans, Bosnians, Pakistanis and Indonesians (HREOC, 2004: 213-214). 
Overall, more than a third of Australian Muslims (36 per cent) were born in Australia (HREOC, 2004: 210). Many are children and grandchildren of the large numbers of Turkish and Lebanese migrants who arrived in the 1960s and 1970s, following the easing of restrictive immigration policies. Smaller numbers of Muslims from Iraq and elsewhere in the Middle East, along with those from North Africa, have arrived more recently, often as refugees (HREOC, 2004: 210). In Australia, Muslims tend to settle in capital cities, with almost half (48 per cent) living in Sydney and another third (31 per cent) living in Melbourne (HREOC, 2004: 213).

Australian Muslims tend to be relatively economically disadvantaged. In 2001, 43 per cent of Australian Muslims (compared with 27 per cent of all Australians) had a weekly income under \$200 (HREOC, 2004: 215). And despite having levels of education similar to the national average, Muslim Australians are more likely to work in blue-collar occupations (HREOC, 2004: 214). Unemployment rates vary, but among some birthplace groups, they are substantially higher than average. For example, among all Lebanon-born people aged 15 years and over, the unemployment rate was 14.5 per cent in 2001, while for those born in Turkey, it was 15.6 per cent; both were approximately double the national rate of 7.4 per cent (DIMA, 2006).

\section{'Defending women's rights' as the new Islamophobia}

The optimistic rhetoric of Australian multiculturalism has always masked a more complex reality of ethnic tensions. In the 1990s, the populist politician Pauline Hanson and her One Nation Party stirred up resentment against Asian and indigenous communities. Since the early 2000s however, top billing for racial vilification has passed to Muslim Australians. A potent combination of moral panics over the alleged criminality of Lebanese Muslim men, the unauthorised arrival of Iraqi and Afghan asylum seekers, and global terrorism has cemented the position of Muslims as the preeminent threat to national security and multicultural harmony in contemporary Australia.

In recent political debates, Muslim Australians have been depicted as qualitatively different from other migrant groups. Their culture and religion are seen as more alien to the Australian mainstream, and their social problems more menacing. This construction of Muslim Australians as a unique threat to national cohesion often rests on concerns about gender roles. Anti-Muslim arguments are frequently founded on Muslim men's alleged oppression of women, whether of Muslim women (who are 'forced' into 'oppressive' practices, such as wearing the veil) or non-Muslim women (who are victims of harassment and rape).

As the Australian Prime Minister, John Howard, stated in February 2006, 'There is within some sections of the Islamic community an attitude towards women which is out of line with mainstream Australian society' (SMH, 2006). Howard argued that this was a problem 'unique' to Muslims that previous migrants did not have: 'For all the conservatism towards women and so forth within some of the Mediterranean cultures, it's as nothing compared with some of the more extreme attitudes' (Megalogenis, 2006). 
Several months later, Howard specified that treating women as equals, along with speaking English, were core 'Australian values' that Muslims had to learn if they were to fully integrate into Australian society. As he told The Australian newspaper:

Fully integrating means accepting Australian values, it means learning as rapidly as you can the English language if you don't already speak it. And it means understanding that in certain areas, such as the equality of men and women ... people who come from societies where women are treated in an inferior fashion have got to learn very quickly that that is not the case in Australia (Kerbaj, 2006a).

Other members of Howard's conservative administration (and interestingly, many female politicians) have initiated heated public discussions about Muslim women and girls' right to wear the headscarf or hijab (Liberal Party MPs, Bronwyn Bishop and Sophie Panopoulos), sharia law (Federal Treasurer, Peter Costello), and, in a more bizarre intervention (in a debate on abortion), the question of whether Muslims will take over the country as Anglo Australians 'abort ourselves almost out of existence' (Liberal MP Danna Vale). Underlying all of these debates has been concern over Muslim Australians' 'refusal' to assimilate to the mainstream Australian culture, most potently encapsulated in the image of veiled women, seen as virtual slaves to a brutal religious code.

Many ordinary Australians agree that Muslims have problematic attitudes to women. In a 2003 survey about Australian public knowledge of Islam, respondents were asked to describe their perceptions of the beliefs held by followers of Islam. More than a third (38 per cent) answered with criticisms of Islam, with 'misogynist' figuring highly, alongside 'fundamentalist' and 'intolerant' (Dunn, 2005: 11). As Dunn comments, 'These are clearly a poor form of knowledge of Islam and Muslims, and may mitigate a more rounded understanding' (2005: 11).

In other Western countries, Islam's alleged misogyny is a key tenet of arguments against the immigration of Muslims. In the US, commentator Brenda Walker argues against immigration from Third World countries because it is tantamount to 'importing misogyny' (Walker 2005). Writing for the conservative US organisation, The Social Contract, Walker (2002: 60) argues:

The newcomer Muslims bring an ancient social structure that is authoritarian and misogynist, where knowledge is an inherited commodity rather than derived through rational inquiry. Western culture, on the other hand, has built upon its Greek, Roman and Renaissance traditions to value democracy, gender equality, individual rights and rational thought.

Gender roles have also featured prominently in the tumultuous European debates on immigration and Muslims, as seen, for example, in the French ban on headscarves in schools, and the murder of Dutch filmmaker and columnist Theo Van Gogh, following the release of his film, Submission, depicting Quranic verses plastered over a naked woman. All of these debates equate Islam with misogyny, which is pitted in opposition to the assumed gender equality of Western societies. 


\section{Misogyny is 'un-Australian': Nationalism and the masculine protection of women}

But it is not just concern for the treatment of Muslim women that has generated this discourse of Muslim misogyny. Islam's alleged oppression of non-Muslim women has produced equally heated debate. In Australia, instances of rape and harassment of women in public spaces have bolstered the image of Muslim men's 'bad attitudes' toward women, and have stimulated a racialised urge to protect 'our women'.

I focus here on the public discourse surrounding the Cronulla riots in December 2005, which saw thousands of largely Anglo-Celtic Australians protesting against the use of Cronulla beach by Lebanese Australians, and ended in crowds of men seeking and violently attacking anyone of 'Middle Eastern appearance'. This was followed by the 'revenge attacks' over the following few days, in which groups of young Lebanese Australian men assaulted people and damaged property in several beachside suburbs.

Cronulla beach is located in Sydney's southern suburbs, within the Sutherland Shire, an area where comparatively few non-Western migrants have settled, and one with a reputation for insularity. The 2001 Census recorded that the Sutherland Shire had one of the highest proportions of Australian-born residents in metropolitan Sydney (78.5 per cent, compared to 62.2 per cent for Sydney as a whole, and 72.6 per cent nationally). Of those born overseas, the most common birthplaces were England, New Zealand and Italy. The vast majority (86.4 per cent) of Sutherland residents spoke only English at home (compared to 66.5 per cent for Sydney, and 80 per cent nationally) (ABS, 2006).

The Shire is relatively comfortable economically, with an unemployment rate of only 3.5 per cent in 2001 (compared to 6.1 per cent for Sydney, and 7.4 per cent nationally). And in 2001 more than a quarter (27.5 per cent) of Sutherland's employed residents were managers, administrators, professionals or associate professionals (compared to 24.2 per cent for Sydney, and 21.9 per cent nationally) (ABS, 2006). Therefore, many of the residents of this comparatively homogeneous, relatively welloff area felt they had much to protect - not only the local beach, but a way of life more generally.

Sunday, December $12^{\text {th }} 2005$ had been designed to be a show of force by local residents. ${ }^{\mathrm{i}}$ The event had been promoted via mobile phone text messages, the key one being:

This Sunday every fucking Aussie in the shire get down to North Cronulla to help support Leb and wog bashing day. Bring your mates down and let's show them this is our beach and they're never welcome back (Jackson 2006).

While the catalyst for the mass gathering was the previous weekend's assault on two surf lifesavers by men of 'Middle Eastern appearance' on Cronulla beach, local residents stated that tensions had been simmering for many years. A central cause of tension was the treatment of women by 'Lebanese' men. 'Bad attitudes' toward women, displayed primarily in the verbal harassment of women in public spaces, had become the touchstone marking Muslim men as the aggressive and threatening 'other'. 
In the words of one local resident, Shaun Donohoe, quoted in The Sydney Morning Herald: 'They look down on our women. They don't really assimilate to our way of life. I've been at war with them for ten years' (McMahon 2005). Another man, interviewed at Cronulla on the day of the riots, said: 'They come down here and they start with their mouth. They just bullshit to everybody. They harass our women. It's their religion' (Martin 2006). At a televised forum on the riot, another local resident, Jason Stevens, spoke of how incidents involving white women and 'Middle Eastern background' men had long caused problems, culminating in the riots:

It was about four years ago when, you know, I was at the beach, and I saw a guy of Middle Eastern background, and he pinched a white Anglo girl on the bum. I went over. Mate, within two minutes I was surrounded by these guys, and I've never experienced fear like that, I'll be honest with you, so that frustration on the day that was shown, it was inexcusable the way the people, you know, enforced it and expressed themselves, absolutely inexcusable, but there were reasons why, which led to that frustration. You got to understand (Martin 2006).

Similar sentiments were expressed by some politicians. Soon after the riots and revenge attacks, the Leader of the National Party in New South Wales, Andrew Stoner, stated in Parliament that as many as three years earlier, he had been informed 'of people from the western suburbs and the south-west of Sydney repeatedly coming to the beach and harassing young females on the beach' (Parliament of NSW, 2005). Another New South Wales Member of Parliament, Carl Scully, remarked: 'I am concerned a small number of Middle Eastern males appear to have a problem with respecting women and I think that was an underlying current in a lot of the Caucasian males with a bit of grog responding and venting their spleen' (Zinn, 2006). The federal Member of Parliament for the area, Bruce Baird, stated: 'I haven't seen the kind of problems we've got now', adding that the visitors were aggressive and had 'anti-female attitudes' (McMahon 2005).

These incidents form part of a larger catalogue of offensive behaviour on the part of young men of 'Middle Eastern appearance', particularly a series of gang rapes in Sydney in the early 2000s, which have been extensively documented and discussed by both academics (see especially Collins, Noble, Poynting and Tabar,, 2000 and Poynting, Noble, Tabar and Collins, 2004) and prominent right-wing media commentators (e.g. Sydney Morning Herald columnist Paul Sheehan; The Australian columnist, Janet Albrechtsen). In these discussions, the same logic is articulated, between misogyny and 'un-Australian' values. For example, discussing the rapes in 2001, the popular Sydney radio host Alan Jones made the connection clear, stating that 'Lebanese Muslim gangs' were 'showering their contempt for Australia and our police on these young girls' (MediaWatch, 2002). In the aftermath of the Cronulla riots, columnist Paul Sheehan stated, 'We've had warning after warning, gang rape after gang rape and there have been hundreds of violent sexual incidents. And that's what sets this subculture apart from previous crimes. It is the sexual tension' (cited in (Zinn 2006). In his more recently published book on a series of gang rapes in Sydney, Sheehan (2006) describes young Muslim men in Australia as a 'cultural time bomb' whose upbringing conditioned them towards sexual violence. 
It is not the intention of this paper to in any way defend men who rape and harass women. Outrage at criminal violence against women is appropriate and legitimate. However, as Collins et al (2000) have argued, the racialised portrayal of these crimes, with the police and media's excessive racial descriptions of defendants as 'Lebanese' or 'Middle Eastern' effectively criminalised an entire migrant community in Australian society, serving only to exacerbate fear and hostility within the broader public. The popular representation of these crimes blamed Lebanese or Muslim culture for its 'inherent' disrespect for women. This enabled the deployment of a rhetorical equation of the mistreatment of women with alien and threatening values. From the beginning, these notorious crimes were overwhelmingly represented as Lebanese or Muslim men raping non-Muslim women, and this made them $a$ particularly un-Australian crime. They were not just crimes against women, but crimes against Australia, generating a racialised urge to protect that formed the core of a resurgent paternalistic nationalism. The Cronulla rioters' efforts to 'reclaim our beach' and protect 'our women' were a display of this nationalism.

In contemporary Australia therefore, women have become a new symbol of the country's vulnerability to extremism and 'alien' values. While the protection of women against foreign men has been a recurring trope throughout Australian history, as will be discussed below, the current anxieties have played out against a particularly potent global backdrop of the war on terror, which views Western-Islamic relations through the framework of a 'clash of civilisations'. For example, after the Cronulla riots, local MP Bruce Baird drew a direct connection between global and local events, claiming that many residents' hostility towards Muslims was related to the death of six local women in the 2002 Bali bombings. The riots were in part revenge for the Bali bombings and September 11, Baird stated (SMH, 2005).

Therefore, in the context of these larger anxieties about terrorism, veiled Muslim women and young Anglo-Celtic rape victims and intimidated beach goers have come to symbolise the looming menace of Islam within the national body politic. Hence Australian nationalism assumes the form of a paternalism centred around the protection of women. Australian masculinity defines itself not only in gendered terms, but also through racialised notions of defending the national honour via the bodies of women.

\section{The grand tradition of colonial feminism: International relations through struggles over women's bodies}

Constructions of national identity and dealings between nation-states have commonly emphasised struggles over women's bodies. Historically, Western colonial powers contrasted the supposed civilised gender regimes of their own societies with the barbarism of colonised societies in order to justify colonialism. As Edward Said's Orientalism (1979) explained, the Orient has long been seen as a site of despotism, irrationality, backwardness and the mistreatment of women. Thus 'liberating' women has been a common colonialist refrain. Colonial feminism, or the feminism 'used against other cultures in the service of colonialism' (Ahmed, 1992: 151), is evident in representations of colonised societies around the world, whose treatment of women was solid evidence of their incapacity for self-governance. 
In India, for example, the British saw women only as passive victims in need of colonial salvation, and passed legislation prohibiting practices such as widow burning, all in the name of advancing civilisation. In these instances, as Spivak notes, 'the agency was always male; the woman was always the victim' (1999: 298). Hence colonialism was about 'white men saving brown women from brown men' (Spivak 1985).

There was no greater symbol of the oppression of 'brown women' than the veil. Throughout the Middle East, veiling - 'the most visible marker of the differentness and inferiority of Islamic societies' - was at the centre of 'the degradation of women', which represented 'the backwardness of Islam' (Ahmed, 1992: 152). Efforts to 'deveil' women were at the forefront of English and French colonists' 'civilising mission'. In the words of Lord Cromer, the British colonial governor of Egypt (18831907), the Islamic practices of veiling and seclusion of women were 'the fatal obstacle' to the Egyptians' 'attainment of that elevation of thought and character which should accompany the introduction of Western civilisation' (cited in Ahmed, 1992: 153).

A racialised paternalism is also evident in Australian history, with colonial authorities justifying their intervention in Indigenous communities by asserting their concern for the welfare of women and girls. As Goodall (1995; 1990) documents, Aboriginal men were depicted as sexual threats to both white and Aboriginal women, and as a result, the majority of Indigenous children who were removed from their families in the early part of the twentieth century were girls. Such instances were part of an effort to define a 'civilised' Australian masculinity in opposition to the immorality and 'unnatural vices' of non-Caucasian men - not only Aboriginal men but other minorities, particularly the Chinese, who, as Moore (1998: 46) notes, were also denigrated for their homosexual activity. These constructions of the barbarism of other cultures with regards to gender relations formed a key pillar of the White Australia Policy, which restricted non-White immigration to the country for most of the twentieth century.

Why have women and gender relations been such a key target of inter-cultural conflicts? As feminist scholars of international relations have noted, violence and war between states has often been legitimised by the construction of the 'protected', who are invariably innocent, pure, and female (Tickner, 2001). Symbolically, women represent the purity and honour of the nation or motherland. As McClintoch (1995: 354) argues, women are 'symbolic bearers of the nation', and this is visually evident in depictions of the nation, from the USA's Lady Liberty, the UK's Britannia, and France's Marianne, to the Singapore Girl (You're a Great Way to Fly). Women are the bearers of future generations, the vehicles for transmitting national values from one generation to the next, and importantly, those most vulnerable to defilement by outsiders (Enloe, 1989: 54, see also Yuval-Davis and Anthias, 1989).

Thus gaining control over the female population of 'the enemy' has been a crucial part of inter-state conflict. As Stoler (1997: 346) notes, sexual domination has long been a social metaphor of European supremacy. And in the words of Said, the sexual submission and possession of Oriental women by European men 'stands for the pattern of relative strength between East and West' (1979: 6). In times of war, the imagery of sexual conquest, rape and penetration are ubiquitous in the depiction of 
military weaponry and offensives. The 'rape of Kuwait' was commonly heard in the 1991 Gulf War, during which US marines were reported to have adorned missiles with the words, 'Bend over, Saddam' (Cohn, 1993: 236).

While in practice, virtually all wars have featured the rape, sexual enslavement, or sexual exploitation of women, and not just by small groups of men, but by army high commands (Nagel, 1998: 257), the official state rhetoric usually articulates a need to protect or liberate enemy women. In the Middle East, the discourse of Islamic societies' oppression of women has continued to legitimate Western intervention. During the 1991 Gulf War, the 'maltreatment of women and their exotic attire' was cited by the US government and media in their rationale for intervention (Moghissi, 1999: 37). After September 11, images of veiled women reached 'epic proportions' (Ayotte and Husain, 2005: 117), as the American crusade against the Taliban became gradually a mission to 'liberate' Afghan women. In the mobilisation for the war on terror, the veil became a powerful 'visual and linguistic signifier of Afghan women's oppression’ (Ayotte and Husain, 2005: 117).

In his 2002 State of the Union address, George W. Bush baldly stated that the US invasion had liberated Afghan women, proclaiming: 'The last time we met in this chamber, the mothers and daughters of Afghanistan were captives in their own homes, forbidden from working or going to school. Today women are free' (Bush, 2002). Interestingly though, perhaps the clearest rhetorical connection of terrorism with the treatment of women came from Laura Bush. In November 2001, Mrs Bush used the president's weekly radio address to launch a 'world-wide effort to focus on the brutality against women and children by the al-Qaida terrorist network', and made the bizarre claim that 'the brutal oppression of women is a central goal of the terrorists' (Bush 2001). As Ayotte and Husain (2005: 124) ask, 'Then why attack the World Trade Center?' Conflating the ruling Taliban with al-Qaida, Mrs Bush repeatedly blamed the 'terrorists' for the oppression of Afghan women.

The US military campaign had been successful in liberating Afghan women, Mrs Bush claimed:

Because of our recent military gains in much of Afghanistan, women are no longer imprisoned in their homes. They can listen to music and teach their daughters without fear of punishment... The fight against terrorism is also a fight for the rights and dignity of women (Bush 2001).

As Arundati Roy (2002) put it, we were asked to believe that the US marines were 'actually on a feminist mission.' Thus the War on Terror clearly revives the well-worn discourse of colonial feminism, using the alleged oppression of foreign women as a moral rationale for Western intervention.

\section{Where are women's voices? The politics of speaking out}

The rhetoric of women's rights is obviously hypocritical when deployed by governments setting out to demonise other cultures. However, a potentially even more 
damaging legacy of this discourse is that it can undermine opportunities for women to contribute to political and community debates. The appropriation of the women's rights discourse by powerful and conservative elements can make it more difficult for Muslim women themselves to articulate their issues and perspectives. When the defence of women's rights is bound so closely with anti-Muslim racism in public discourse, Muslim women's own concerns with patriarchal practices risk fuelling further racism.

As Ahmed (1992: 167) argues, the discursive connection of culture and women, dating to colonial times, has ever since 'trapped the struggle for women's rights with struggles over culture'. Arguments for women's rights are often perceived and represented by opponents as arguments 'about the innate merits of Islam and Arab culture comprehensively’ (Ahmed, 1992: 167). Criticisms of particular laws and customs cannot be made without implicating the intrinsic merits of Islam or Arab culture.

Many feminists have written of this 'double bind' of 'gendered racism' and 'racialized sexism' that minority women often find themselves in (Adelman, Erez, and Shalhoub-Kevorkian, 2003: 117). While they face racism and sexism from the majority society, they also confront sexism and male domination in their own community. In this bind, speaking out about oppressive practices in their own community, such as gendered violence, can result in being treated like a traitor by their own community, while also reinforcing negative stereotypes of the majority society of oppressive, backward cultures. As Adelman et al (2003: 117) explain, 'Fear of reinforcing the dominant group's stereotypes, possibly leading to further racism and discrimination toward the minority group, effectively silences minority abused women’ (see also Nayak, 2006: 49; Rozario, 1996: 218).

Many Muslim community leaders in Australia are responding to the onslaught against them by attempting to unify the community and defend Islam at all costs. This is an understandable approach, but it can have negative consequences for women. For example, Joumanah El Matrah, manager of the Islamic Women's Welfare Council of Victoria, has criticised male community leaders for assuming the role of 'the guardians and keepers of tradition', and conflating the holding together of the community with maintaining traditional practices and beliefs that can oppress women (ABC, 2005). In Sydney, the vice-chair of the Ethnic Communities Council, Saeed Khan (2006), has questioned why conservative religious leaders have such a stranglehold over any public representation of the Muslim community, arguing that these men do not represent the majority of Muslims in Australia, especially the concerns of young Muslims and Muslim women.

There are growing numbers of Australian Muslim women publicly speaking about issues of importance to them, such as violence against women, and women's access to community organisations and mosques. However, these debates always occur in the tense environment of anti-Muslim hostility on the one hand, and internal Muslim community regulation on the other. This can sharply curtail public statements that are perceived to potentially damage the Muslim community. The debates around the comments of Australia's most senior Muslim cleric, Sheikh Taj Aldin al-Hilaly, are a perfect example. In October 2006, the Sheikh compared immodestly dressed women to 'uncovered meat' attracting the attention of rapists. These remarks were met with 
vigorous protest from Muslim women and men from around Australia. For example, Aziza Abdul-Halim, president of the Muslim Women's National Network of Australia, stated that they were 'below and beyond any comment and do not deserve any consideration' (Kerbaj, 2006b).

However, in the weeks following the scandal, as the Muslim community once again felt itself under attack, public statements became more protective of the Sheikh, who became seen by some groups as a victim of media sensationalism and political vilification. On October 30, the United Muslim Women Association issued a media release defending the Sheikh as a 'champion of women's rights' and expressing disappointment at 'our elected leaders using the current crises for political mileage at the expense of the Muslim community' (UMWA, 2006). A community statement issued soon after, and signed by 34 Muslim organisations, similarly condemned the 'hysteria and sensationalism' characterising the debate (Kilani, 2006). Gradually lost in much of the discussion was the issue of violence against women, as the more 'urgent' priority of defending the community prevailed. Muslim women seeking to critically discuss sexual violence and attitudes toward women found it virtually impossible to do so without fuelling further racism against their community. As one Muslim feminist expressed it, Muslim women became 'trapped' between the media and politicians on one side, and 'misogyny from elements in their own community' on the other (Hussein, 2006: 1).

\section{Conclusion}

In many Western nations today, Muslims have become the pre-eminent 'alien within'. The global war on terror, and local anxieties around 'ethnic crime' and Muslims' 'refusal' to assimilate have given rise to a virtually unprecedented Islamophobia in public discourse. In countries like Australia, expressions of national identity and nationalism increasingly rely on anti-Muslim sentiment. A key part of this Islamophobia is Islam's alleged oppression of women, evidenced in the 'maltreatment' of both Muslim and non-Muslim women.

This paper has shown how anti-Muslim racism is articulated in a paternalistic nationalism that seeks to protect women, whether they are Muslim women 'forced' to wear the veil or non-Muslim women as victims of sexual assault by Muslim men. This paternalism draws on a long history of colonial feminism, which for centuries has used the discourse of women's rights to condemn 'inferior' cultures. Globally, this colonial feminism was most clearly evident in the mobilisation for war on Afghanistan, presented as a campaign to 'liberate' women from the Taliban. In Australia, the same logic is at work in efforts to protect 'our women' from the misogyny of Muslims, as seen in the midst of the Cronulla riots.

The appropriation of the discourse of women's rights by mainstream political leaders ultimately restricts the space available for open discussions within communities, and in particular, undermines women's ability to speak about their own concerns. In order to create a space for this discussion to occur, we need to reclaim the discourse of 
women's rights from conservative politicians and commentators, and break the stifling link that currently exists between defending women and a virulent antiMuslim nationalism. Only then will there be the freedom and safety necessary for cultural transformation to occur within Muslim communities, and Australian society at large.

\section{References}

ABC (Australian Broadcasting Corporation). (2005). Muslim women in Australia. In The Religion Report. 26 January, ABC Radio National. Available from http://www.abc.net.au/rn/talks/8.30/relrpt/stories/s1290321.htm. Accessed: 14 February 2005.

ABS (Australian Bureau of Statistics). (2006). 2001 Census Data. Available from http://www.abs.gov.au/WEBSITEDBS/D3310114.nsf/Home/census. Accessed: 20 December 2006.

Adelman, Madelaine, Erez, Edna and Shalhoub-Kevorkian, Nareda. (2003). Policing violence against minority women in multicultural societies: 'Community' and the politics of exclusion. Police and Society, 7, 105-133.

Bush, L. (2001). "Radio Address by Mrs Bush." Retrieved 19 April 2006, from http://www.whitehouse.gov/news/releases/2001/11/20011117.html.

Jackson, L. (2006). Riot and Revenge. Four Corners. Australia, ABC TV.

Martin, R. (2006). After the Riots. 60 Minutes. Australia, Channel 9.

McMahon, N. (2005). A lesson in beach etiquette, Shire-style. The Sydney Morning Herald: 3.

Spivak, G. (1985). "Can the Subaltern Speak? Speculations on widow sacrifice." Wedge 7-8: 120-130.

Walker, B. (2005). "Why multiculturalism is a graude and a disaster for women's rights." Retrieved 24 April 2006, from http://www.limitstogrowth.org/WEBtext/multiculturalism-fraud.html.

Zinn, C. (2006). Middle Eastern appearance. Sunday. Australia, Channel 9.

\footnotetext{
${ }^{\mathrm{i}}$ However, it should be noted that many of the men who were eventually charged with offences relating to the riots were not residents of the Sutherland Shire, and many local residents expressed their anger at the involvement of external neo-Nazi groups in the riots (SMH, 2005).
} 